\title{
Culturable phylogenetic diversity of the phylum 'Bacteroidetes' from river epilithon and coastal water and description of novel members of the family Flavobacteriaceae: Epilithonimonas tenax gen. nov., sp. nov. and Persicivirga xylanidelens gen. nov., sp. nov. \\ Correspondence John C. Fry Fry@Cardiff.ac.uk

\author{
Louise A. O'Sullivan, ${ }^{1}$ Joachim Rinna, ${ }^{2}$ Gavin Humphreys, ${ }^{1}$ \\ Andrew J. Weightman ${ }^{1}$ and John C. Fry ${ }^{1}$ \\ ${ }^{1,2}$ Cardiff School of Biosciences ${ }^{1}$ and School of Earth, Ocean and Planetary Sciences ${ }^{2}$, Cardiff \\ University, PO Box 915, Main Building, Park Place, Cardiff CF10 3TL, UK
}

\section{INTRODUCTION}

Members of the phylum 'Bacteroidetes' (previously known as Cytophaga-Flavobacterium-Bacteroides) are seemingly omnipresent in aquatic environments (Reichenbach, 1992). Members have been identified in a diverse range of freshwater and marine habitats, including temperate rivers (Böckelmann et al., 2000), freshwater lakes (McCammon et al., 1998), marine sediments (Humphry et al., 2001), sea ice (Brown \& Bowman, 2001), hypersaline lakes (Dobson et al., 1993) and saline hot springs (Tenreiro et al., 1997). Fluorescent in situ hybridization studies indicate that members of the 'Bacteroidetes' are second only to the Proteobacteria in terms of aquatic abundance (Glöckner et al., 1999; Simon et al., 1999; Cottrell \& Kirchman, 2000b).

Published online ahead of print on 18 November 2005 as DOI 10.1099/ijs.0.63941-0.

The GenBank/EMBL/DDBJ accession numbers for the 16S rRNA gene sequences of Epilithonimonas tenax $\mathrm{EP} 105^{\top}$ and Persicivirga xylanidelens SW256 ${ }^{\top}$ are AF493696 and AF493688, respectively.
Bacteroidetes have been implicated as major utilizers of high-molecular-mass dissolved organic matter in marine ecosystems (Cottrell \& Kirchman, 2000a) and are often abundant in nutrient-rich waters where biomacromolecules accumulate (Reichenbach, 1989). Despite their abundance and apparent ecological significance, bacteroidetes are underrepresented in culture collections when compared with other abundant phyla such as the Proteobacteria. However, in recent years there has been a surge of publications describing novel genera within the phylum 'Bacteroidetes'; this has been mainly within the family Flavobacteriaceae including Aquimarina (Nedashkovskaya et al., 2005b), Gillisia (Van Trappen et al., 2004), Kordia (Sohn et al., 2004), Ulvibacter (Nedashkovskaya et al., 2004b) and Formosa (Ivanova et al., 2004). There have also been some novel genera described recently outside the family Flavobacteriaceae, including Adhaeribacter (Rickard et al., 2005), Hongiella (Yi \& Chun, 2004), Arcicella (Nikitin et al., 2004) and Belliella (Brettar et al., 2004). In addition, the novel family Cryomorphaceae within the phylum 'Bacteroidetes' 
was recently described containing five new genera, namely Brumimicrobium, Cryomorpha, Crocinitomix, Owenweeksia and Fluviicola (Bowman et al., 2003; Lau et al., 2005; O'Sullivan et al., 2005).

The overall aim of this study was to investigate and compare the phylogenetic diversity of isolates within the phylum 'Bacteroidetes' from the relatively high-nutrient freshwater and marine habitats of river epilithon (River Taff, Cardiff, UK) and coastal sea water (Hope Cove, Plymouth, UK). A cultivation-based approach was employed involving standard spread-plate isolation techniques to determine whether this traditional approach still yielded novel and interesting strains of bacteroidetes. This study is the first in which a large selection of isolates obtained on agar plates were initially screened with 'Bacteroidetes'-specific 16S rRNAgene-targeted oligonucleotide probes (Manz et al., 1996; O'Sullivan et al., 2002). This ensured accurate identification of colonies belonging to the 'Bacteroidetes' before undertaking an assessment of culturable diversity based on $16 \mathrm{~S}$ rRNA gene sequence phylogeny.

Polyphasic characterization of one freshwater epilithon isolate $\left(\mathrm{EP} 105^{\mathrm{T}}\right)$ and one coastal sea-water isolate $\left(\mathrm{SW} 256^{\mathrm{T}}\right)$ enabled the description of two novel aquatic members of the Flavobacteriaceae: Epilithonimonas tenax gen. nov., sp. nov. and Persicivirga xylanidelens gen. nov., sp. nov.

\section{METHODS}

Samples. River epilithon samples were collected from the River Taff in Cardiff, UK, in January 2000 (Ordnance Survey map reference SO783165). Five stones were collected in sterile plastic bags and processed within $1 \mathrm{~h}$ of collection. Epilithon samples were obtained by scrubbing each stone with a sterile toothbrush in $30 \mathrm{ml}$ sterile deionized water containing $1 \mu \mathrm{l}$ Tween $201^{-1}$ (Burton et al., 1982). Samples from all five stones were combined and homogenized with $5 \mathrm{~min}$ treatment in a stomacher (O'Sullivan et al., 2002). Coastal sea-water samples were obtained from Hope Cove near Plymouth, UK, in March 2000 (Ordnance Survey map reference SX675395). Sea water was collected by wading into the sea and opening sterile Duran bottles under the surface. The bottles were transported to the laboratory in a cool box and processed within $5 \mathrm{~h}$.

Bacterial isolation. Bacterial strains were isolated from river epilithon and coastal sea water. Epilithon samples were serially diluted in sterile deionized water containing $1 \mu \mathrm{l}$ Tween $201^{-1}$ (Christensen \& Cook, 1972). The spread-plate technique was used with six different agar media containing $20 \mu \mathrm{g}$ cycloheximide $\mathrm{ml}^{-1}$ : plate count agar (PCA; Oxoid), PCA plus $50 \mu \mathrm{g}$ kanamycin $\mathrm{ml}^{-1}$ (Flint, 1985), medium M1 (Weeks, 1955), PMYA II (Christensen \& Cook, 1972), casein-yeast-tryptone (CYT; Holmes, 1992) and casein-peptonestarch (CPS; Staples \& Fry, 1973). Sea water samples were serially diluted in aged sea water from a circulating marine aquarium that had been filter-sterilized through a sterile $0 \cdot 2 \mu \mathrm{m}$ pore membrane after adjustment to $36 \%$ salinity by dilution with distilled water. Three different solid media were made with this filter-sterilized sea water: PCA plus $50 \mu \mathrm{g}$ kanamycin $\mathrm{ml}^{-1}$, CYT and R2A (Difco Bacto R2A agar). All media were adjusted to $\mathrm{pH} 7 \cdot 2$ before sterilization by autoclaving at $121^{\circ} \mathrm{C}$ for $15 \mathrm{~min}$. Agar plates were incubated at $20^{\circ} \mathrm{C}$ for 10 days. Colonies showing characteristic spreading and/or yellow, orange, pink or red pigmentation were selected as putative members of the 'Bacteroidetes'. Individual colonies were subcultured twice on their original isolation medium, before being purified on PCA (containing aged sea water for marine isolates). After isolation and purification, marine isolates were cultured on media prepared with artificial sea water $(24 \cdot 7 \mathrm{~g} \mathrm{NaCl}, 0.7 \mathrm{~g} \mathrm{KCl}$, $6.3 \mathrm{~g} \mathrm{MgSO}_{4} .7 \mathrm{H}_{2} \mathrm{O}, 4.6 \mathrm{~g} \mathrm{MgCl}_{2} \cdot 6 \mathrm{H}_{2} \mathrm{O}, 1 \mathrm{~g}$ anhydrous $\mathrm{CaCl}_{2}$ and $0 \cdot 2 \mathrm{~g} \mathrm{NaHCO}_{3}$ per litre distilled water; Dawson et al., 1969). Strains were maintained as viable cultures on low-nutrient media at $4{ }^{\circ} \mathrm{C}$ using CYT agar for epilithon strains and SAP2 agar (Holmes, 1992) for sea-water strains. Strains were also cryopreserved at $-80^{\circ} \mathrm{C}$ in FXAG liquid medium (epilithon isolates) or SP5 liquid medium (sea-water isolates) containing 30\% glycerol (Holmes, 1992). Epilithon isolates were designated 'EP' and coastal sea-water isolates were designated 'SW.'

Molecular analysis. 16S rRNA gene PCR amplification with general bacterial primers $27 \mathrm{~F}$ and $1392 \mathrm{R}$, sequencing and phylogenetic tree construction were performed as described previously (O'Sullivan et al., 2004). DNA base composition and DNA-DNA hybridization experiments were conducted at the Deutsche Sammlung von Mikroorganismen und Zellkulturen GmbH (DSMZ). DNA isolation and DNA G $+\mathrm{C}$ content analysis were performed as described previously (O'Sullivan et al., 2005). DNA-DNA hybridization was carried out as described by De Ley et al. (1970), with the modifications described by Huß et al. (1983), using a Cary 100 Bio UV/VIS spectrophotometer equipped with a Peltier-thermostatted $6 \times 6$ multicell changer and a temperature controller with in situ temperature probe (Varian).

Selection of isolates for phylogenetic analysis. The $16 \mathrm{~S}$ rRNA gene PCR product from each isolate was immobilized on nylon membranes using a slot-blot manifold (O'Sullivan et al., 2002). The membranes were hybridized against the 'Bacteroidetes'-specific $16 \mathrm{~S}$ rRNA gene-targeted oligonucleotide probes CF319a/b (Manz et al., 1996) and CFB560 (O'Sullivan et al., 2002). 'Bacteroidetes' strains with positive hybridization signals were grouped according to their colony morphology on PCA (containing artificial sea water for marine isolates). Features investigated were colour, transparency, spreading and texture (Smibert \& Krieg, 1994). A selection of strains with representative colony morphologies was selected for phylogenetic analysis based on $16 \mathrm{~S}$ rRNA gene sequence.

Fatty acid analysis. Strain EP $105^{\mathrm{T}}$, Chryseobacterium indoltheticum NCIMB $2220^{\mathrm{T}}$ and Elizabethkingia meningoseptica NCTC $10016^{\mathrm{T}}$ were cultured on tryptone soy agar (TSA; Oxoid) for $24 \mathrm{~h}$ at $25^{\circ} \mathrm{C}$. Strain SW256 ${ }^{\mathrm{T}}$ was grown on marine agar 2216 (MA2216; Difco) for 3 days at $20^{\circ} \mathrm{C}$. Biomass was collected by washing with PBS (Sigma) and freeze-dried. Fatty acid analyses were carried out as described previously (O'Sullivan et al., 2005).

Phenotypic analysis. The majority of phenotypic tests utilized in this study were performed as described previously (O'Sullivan et al., 2005). Prior to experimental investigation, bacteria were revived from $-80^{\circ} \mathrm{C}$ freezer stocks at $20^{\circ} \mathrm{C}$ on either PCA or nutrient agar (NA; Oxoid). Media were supplemented with artificial sea water for cultivation and testing of marine bacteria. All 'Bacteroidetes' isolates were tested for the presence of flexirubin pigments and for the ability to form spreading colonies on PCA, CYT and VY2 agar (the latter has been noted to stimulate spreading; Reichenbach, 1992). Additional phenotypic tests (see Tables 1 and 2) were performed on strains $\mathrm{EP} 105^{\mathrm{T}}$ and $\mathrm{SW} 256^{\mathrm{T}}$, with some also carried out on the reference bacteria, E. meningoseptica and C. indoltheticum. Gliding motility was detected by phase-contrast microscopy of suspensions from the edges of colonies; strain $\mathrm{EP} 105^{\mathrm{T}}$ was grown on TSA and strain SW256 ${ }^{\mathrm{T}}$ was grown on MA2216 and both were incubated under high moisture conditions for 3 days. Strains were also characterized with Biolog GN2 Microplate (Biolog) kits processed according to the manufacturer's instructions, with the exceptions 
Table 1. Characteristics that differentiate strain EP105 ${ }^{\top}$ from the type strains of phylogenetically related species in the genera Bergeyella, Chryseobacterium, Elizabethkingia, Kaistella, Riemerella and Sejongia

Taxa: 1, Epilithonimonas tenax sp. nov. EP105 ${ }^{\mathrm{T}}$; 2, B. zoohelcum; 3, C. balustinum; 4, C. daecheongense; 5, C. defluvii; 6, C. formosense; 7, C. gleum; 8, C. indologenes; 9, C. indoltheticum; 10, C. joostei; 11, C. scophthalmum; 12, E. meningoseptica; 13, E. miricola; 14, K. koreensis; 15, R. anatipestifer; 16, R. columbina; 17, S. antarctica. Data were obtained from this study or were cited by other studies (Kim et al., 2004, 2005a; Yi et al., 2005; Young et al., 2005). All species were positive for catalase and oxidase activities, but did not show gliding motility and were Gram-negative. +, Positive; -, negative; w, weakly positive; ND, no data; v, variable between strains.

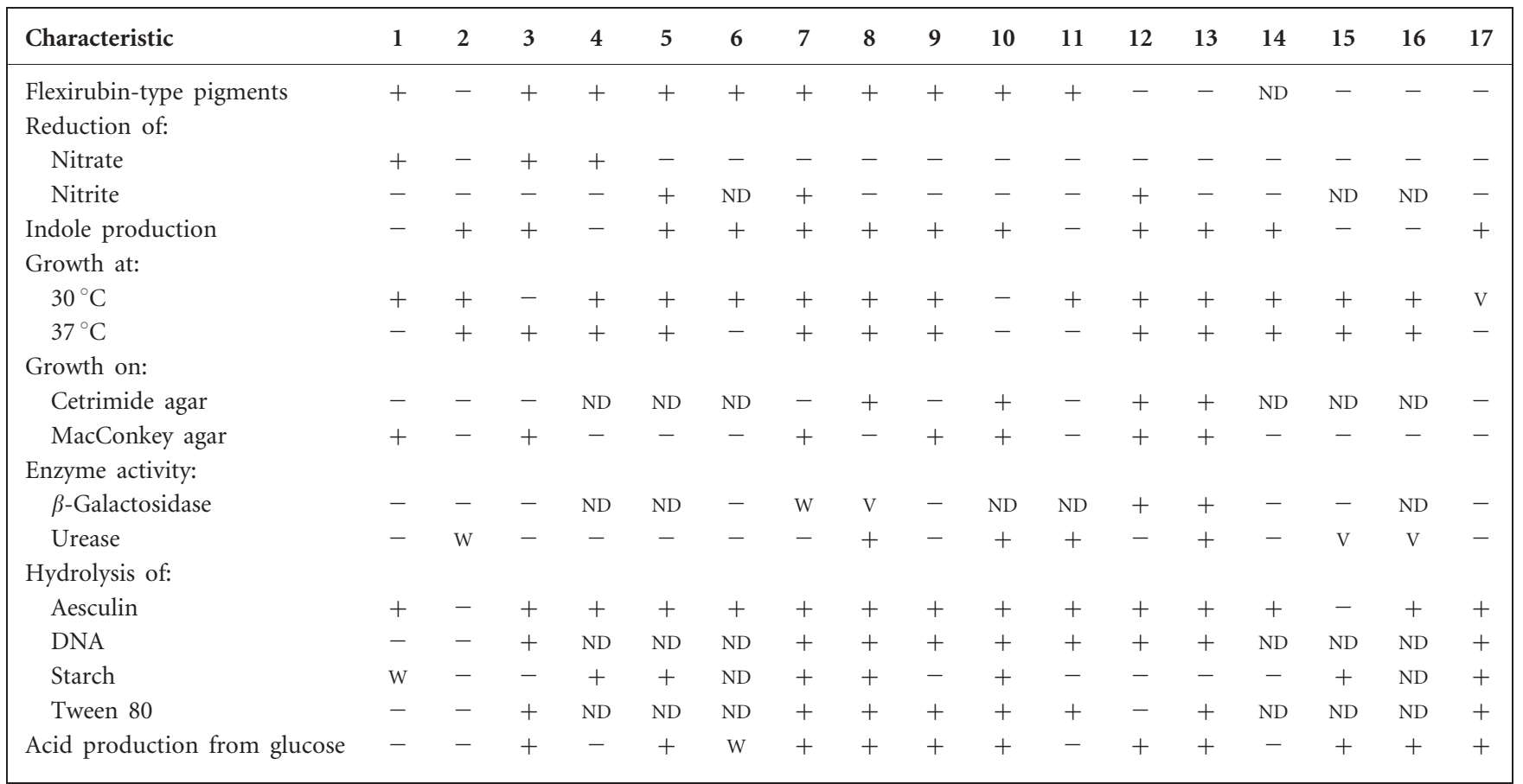

that incubation was at $20{ }^{\circ} \mathrm{C}$ and strain $\mathrm{SW} 256^{\mathrm{T}}$ was inoculated in artificial sea water containing Casamino acids and trace elements (O’Sullivan et al., 2005).

\section{RESULTS AND DISCUSSION}

\section{Phylogenetic diversity of 'Bacteroidetes' isolates}

A collection of 382 isolates exhibiting spreading colonies or yellow, orange, pink or red pigmentation was isolated and purified from River Taff epilithon (145) and Hope Cove coastal sea water (237). Overall, $74 \cdot 3 \%$ (284/382) of the isolates hybridized with at least one of the 'Bacteroidetes' specific 16S rRNA gene-targeted oligonucleotide probes. These 'Bacteroidetes'-positive isolates were then grouped into 17 types according to colony morphology and 59 representative isolates from these morphologically similar types were selected for phylogenetic analysis. Fig. 1 shows examples of most of the typical colony morphologies encountered in this study. The 16S rRNA gene sequences of 55 of these isolates were affiliated with the phylum 'Bacteroidetes' (55/59 or $93.2 \%$; 37 epilithon, 18 sea-water isolates) and 52 of the isolates belonged to the family Flavobacteriaceae (52/55 or $94.5 \%$; Fig. 2 ). The three 'Bacteroidetes' isolates which did not belong to the Flavobacteriaceae were isolates
EP211, EP316 and EP293 (GenBank accession numbers AF493691-AF493693). EP211 and EP293 had 96-97\% sequence similarity to Pedobacter heparinus ATCC $13125^{\mathrm{T}}$ (GenBank accession number M11657) and EP293 had $93 \%$ sequence similarity to Flectobacillus major ATCC $29496^{\mathrm{T}}$ (GenBank accession number M62787).

Interestingly, there was no relationship between phylogeny and the original isolation medium. Some isolates with $>97 \% 16$ S rRNA gene sequence similarity were isolated on different media and vice versa (data not shown). In addition, there was no relationship between phylogeny and colony morphology, with some closely related bacteria producing distinct colonies (data not shown). This suggests that colony morphology in the 'Bacteroidetes' is not a good indicator of phylogeny and so, in future, a sequence-based screening method would be better for diversity studies. The ability of colonies to spread on the agar media was sporadically distributed. This was particularly obvious within the genus Flavobacterium, where 23 isolates could spread and 11 isolates could not. Spreading can be tentatively attributed to gliding motility which was proposed to be an ancestral property lost by some members of the 'Bacteroidetes' (Woese et al., 1990). The presence of flexirubin-type pigments was also much more prevalent in freshwater epilithon isolates 
Table 2. Characteristics that differentiate strain SW $256^{\top}$ from phylogenetically related genera of the family Flavobacteriaceae

Taxa: 1, Persicivirga xylanidelens sp. nov. SW256 ${ }^{\mathrm{T}}$; 2, Aquimarina; 3, Cellulophaga; 4, Gillisia; 5, Kordia; 6, Mesonia; 7, Polaribacter, 8, Psychroflexus; 9, Salegentibacter, 10, Stanierella; 11, Tenacibaculum. Data are from this and other studies (Dobson et al., 1993; Bowman et al., 1998; Gosink et al., 1998; Johansen et al., 1999; McCammon \& Bowman, 2000; Suzuki et al., 2001; Nedashkovskaya et al., 2003, 2005b; Sohn et al., 2004; Van Trappen et al., 2004). All genera were Gram-negative. +, Positive; -, negative; W, weakly positive; ND, no data; $v$, variable between strains.

\begin{tabular}{|c|c|c|c|c|c|c|c|c|c|c|c|}
\hline Characteristic & 1 & 2 & 3 & 4 & 5 & 6 & 7 & 8 & 9 & 10 & 11 \\
\hline Gliding motility & - & + & + & - & - & - & - & $\mathrm{V}$ & - & - & + \\
\hline $\begin{array}{l}\text { Flexirubin type } \\
\text { pigments }\end{array}$ & - & + & - & - & - & - & - & - & - & - & - \\
\hline Nitrate reduction & - & - & $\mathrm{V}$ & - & + & - & - & - & + & - & $\mathrm{V}$ \\
\hline \multicolumn{12}{|l|}{ Growth at: } \\
\hline $4{ }^{\circ} \mathrm{C}$ & + & + & + & - & + & + & + & + & + & + & $\mathrm{V}$ \\
\hline $20^{\circ} \mathrm{C}$ & + & + & + & + & + & + & - & - & + & + & + \\
\hline $30^{\circ} \mathrm{C}$ & - & + & + & $\mathrm{W}$ & + & + & - & - & + & + & $\mathrm{V}$ \\
\hline $37^{\circ} \mathrm{C}$ & - & - & - & - & + & - & - & - & - & - & $\mathrm{V}$ \\
\hline \multicolumn{12}{|c|}{ Growth on $\mathrm{NaCl}(\%)$ : } \\
\hline 0 & - & - & - & - & - & - & - & - & + & - & - \\
\hline $2 \cdot 5$ & + & + & + & + & + & + & + & - & + & + & + \\
\hline $15 \cdot 0$ & - & - & - & - & - & + & ND & $\mathrm{V}$ & + & - & $\mathrm{V}$ \\
\hline \multicolumn{12}{|l|}{ Enzyme activity: } \\
\hline Catalase & - & + & + & + & - & + & - & + & + & - & + \\
\hline Oxidase & - & + & - & + & + & + & - & + & + & + & + \\
\hline \multicolumn{12}{|l|}{ Hydrolysis of: } \\
\hline Aesculin & - & ND & ND & + & - & ND & $\mathrm{V}$ & $\mathrm{V}$ & + & ND & - \\
\hline Agar & - & - & + & - & - & - & - & - & - & + & - \\
\hline Starch & - & + & + & - & + & - & + & + & + & - & V \\
\hline Tween 80 & + & + & $\mathrm{V}$ & - & $\mathrm{ND}$ & + & ND & + & + & + & + \\
\hline $\begin{array}{l}\text { Acid production } \\
\text { from glucose }\end{array}$ & - & - & + & - & - & - & + & + & + & - & $\mathrm{V}$ \\
\hline
\end{tabular}

( $73 \%$ or $27 / 37$ ) than in sea-water isolates $(11 \%$ or $2 / 18)$, a feature previously recognized by Reichenbach et al. (1980).

\section{Putative taxonomy of Flavobacteriaceae isolates}

The isolates retrieved from this study can be tentatively compared with the current taxonomy of the family Flavobacteriaceae based on 16S rRNA gene sequence analysis. However, a full polyphasic characterization would be required for certainty (Vandamme et al., 1996).

Thirty-four isolates, mainly from river epilithon, were closely related to members of the genus Flavobacterium and potentially represented strains of existing or novel species (Fig. 2). For example, the $16 \mathrm{~S}$ rRNA gene sequence of Flavobacterium johnsoniae DSM 425 was almost identical

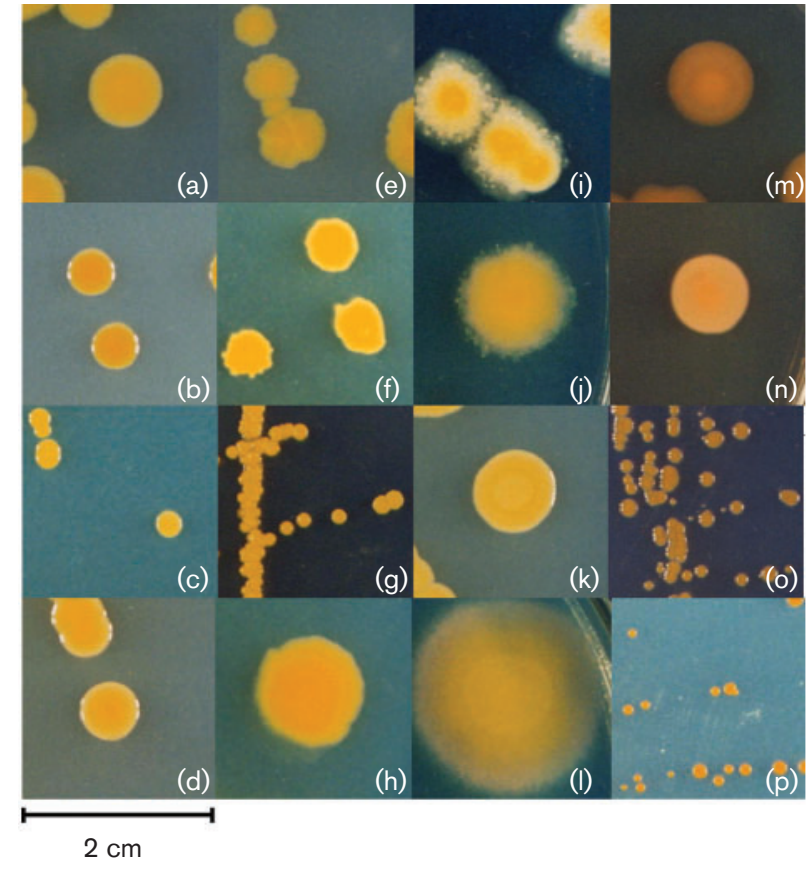

Fig. 1. Colony morphologies of a selection of strains belonging to the 'Bacteroidetes' isolated from River Taff epilithon and Hope Cove coastal sea water. Growth was on PCA (PCA plus artificial sea water for marine strains) for 1 week at $20^{\circ} \mathrm{C}$. (a) EP101; (b) EP248; (c) SW254; (d) Epilithonimonas tenax EP105'; (e) EP240; (f) SW268; (g) SW58; (h) EP252; (i) SW265; (j) EP286; (k) EP134; (I) EP233; (m) EP293; (n) EP211; (o) Persicivirga xylanidelens SW256 ${ }^{\top}$; (p) SW62. Note that colour rendition in these photographs does not always match that observed by eye, but gives an idea of the range of colours observed for these isolates. Bar, $2 \mathrm{~cm}$.

to those of isolates EP286, EP300 and EP246; Flavobacterium saccharophilum NCIMB $2072^{\mathrm{T}}$ was identical to isolate EP251; but isolate SW254 was only $96.5 \%$ similar to Flavobacterium frigidarium ATCC $700810^{\mathrm{T}}$. EP333 and EP131 branch deeply within the genus and so might represent novel species.

Most of the sea-water isolates were most closely related to genera other than Flavobacterium (Fig. 3). For example, SW258 and SW274 potentially belonged to the genus Tenacibaculum (Suzuki et al., 2001), showing 98\% 16S rRNA gene sequence similarity to Tenacibaculum ovolyticum IAM $14318^{\mathrm{T}}$ (GenBank accession number AB032506) and other strains of this species (see Fig. 3). Strains SW7, SW19 and SW146 possibly represented novel species of the genus Polaribacter (Gosink et al., 1998), exhibiting 96-97\% 16S rRNA gene sequence similarity to each other and 94-96\% similarity to the four recognized Polaribacter species. Seawater isolates SW72, SW265 and SW285 were potentially members of the genus Cellulophaga (Johansen et al., 1999). Strain SW72 was most similar to Cellulophaga fucicola NN015860 ${ }^{\mathrm{T}}$ (GenBank accession number AJ005973; 94 \%; 


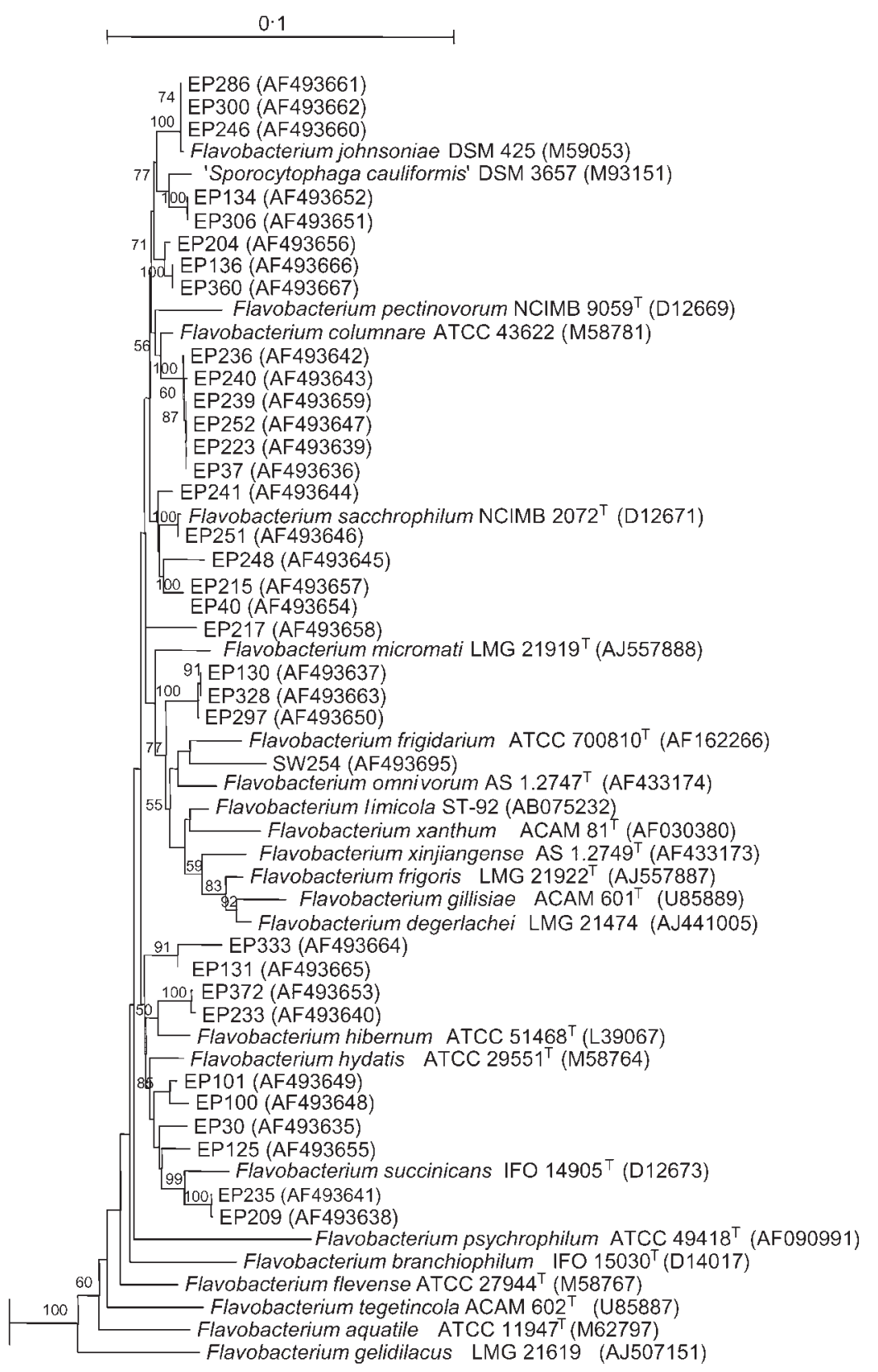

Fig. 2. Phylogenetic tree of $16 \mathrm{~S}$ rRNA gene sequences illustrating relationships between River Taff epilithon and Hope Cove coastal sea-water 'Bacteroidetes' isolates and members of the genus Flavobacterium. Sequences were obtained from GenBank at the National Centre for Biotechnology Information website (http://www.ncbi.nlm.nih.gov). Sequences were aligned using CLUSTAL $\mathrm{W}$ and the alignments were trimmed to $1250 \mathrm{bp}$. The trees were reconstructed with the neighbour-joining and Jukes-Cantor algorithms and were rooted with Bacteroides fragilis ATCC $25285^{\top}$. Bootstrap values from 100 replicate trees are shown at the nodes. Bar, $10 \%$ difference in nucleotide sequence. data not shown), while strains SW265 and SW285 were $99 \%$ related to each other and to Cellulophaga baltica NN015840 ${ }^{\mathrm{T}}$. Strains SW58, SW62, SW152 and SW334 potentially represented novel species of the genus Aquimarina (Nedashkovskaya et al., 2005b) since they formed a monophyletic lineage with Aquimarina muelleri KMM $6020^{\mathrm{T}}$ (95-98\%). Strain SW268 formed a monophyletic lineage with Maribacter sedimenticola KMM 3903 ${ }^{\mathrm{T}}(97 \%)$ and possibly represented a novel species of the genus Maribacter (Nedashkovskaya et al., 2004a). Strain SW269 had 95-96 \% 16S rRNA gene sequence similarity to members of the genus Winogradskyella (Nedashkovskaya et al., 2005a), whilst SW325 was closely related to Psychroserpens burtonensis ACAM $188^{\mathrm{T}}(95 \%)$.

\section{Phylogenetic differentiation between members of the Flavobacteriaceae from freshwater and marine habitats}

The Flavobacteriaceae isolates showed phylogenetic relationships which strongly correlated with environmental origin. Freshwater epilithon strains were affiliated almost exclusively to the genus Flavobacterium (Bernardet et al., 1996; Fig. 2), the only exception being isolate $\mathrm{EP} 105^{\mathrm{T}}$ (Fig. 4). Nearly all sea-water strains belonged to a monophyletic branch typified by marine genera such as Aequorivita, Cellulophaga, Polaribacter, Tenacibaculum and Zobellia (Fig. 3). The only exception was isolate SW254, which was probably within the genus Flavobacterium. This phylogenetic 


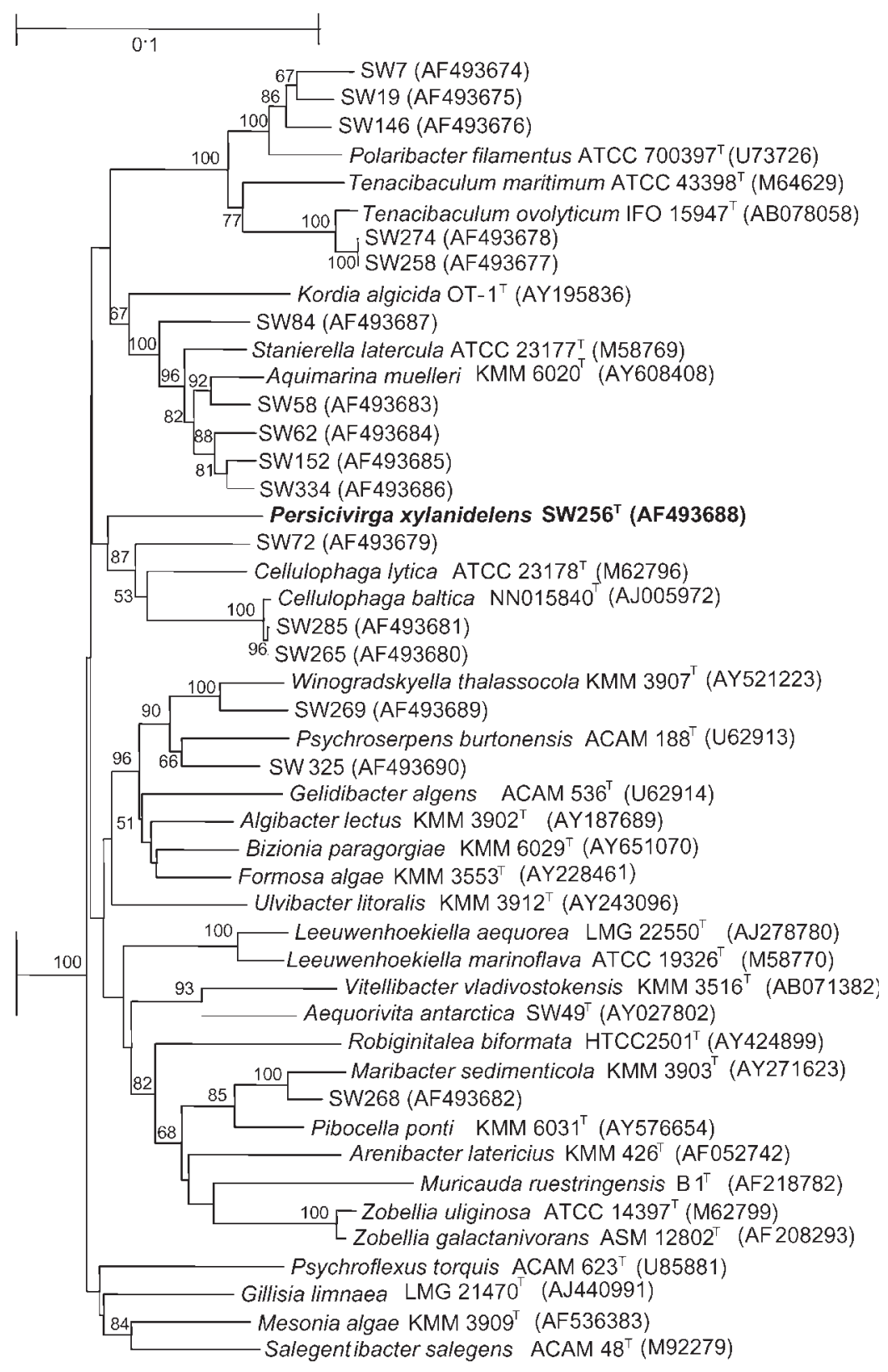

Fig. 3. Phylogenetic tree of $16 \mathrm{~S}$ rRNA gene sequences illustrating relationships between Hope Cove coastal sea-water 'Bacteroidetes' isolates and members of the genera Aequorivita, Algibacter, Arenibacter, Aquimarina, Bizionia, Cellulophaga, Formosa, Gelidibacter, Gillisia, Kordia, Leeuwenhoekiella, Maribacter, Mesonia, Muricauda, Pibocella, Polaribacter, Psychroflexus, Psychroserpens, Robiginitalea, Salegentibacter, Stanierella, Tenacibaculum, Ulvibacter, Vitellibacter, Winogradskyella and Zobellia. The tree was constructed as described for Fig. 2. Bootstrap values from 100 replicate trees are shown at the nodes. Bar, $10 \%$ difference in nucleotide sequence. distinction between freshwater and marine members of the Flavobacteriaceae was originally noted by Reichenbach et al. (1980) and Paster et al. (1985). However, this distinction is not found in all genera within the family. For example, some species of the genera Flavobacterium, Chryseobacterium and Sejongia can grow on media with and without added salt.

Overall, the coastal sea-water isolates exhibited greater 16S rRNA gene sequence diversity than the freshwater epilithon isolates. Sea-water isolates had $88.9 \%(16 / 18)$ unique sequence similarity groups (a sequence or group of sequences with $>97 \%$ sequence identity), compared with only $43 \cdot 2 \%(16 / 37)$ for the epilithon isolates. A greater proportion of sea-water isolates $(13 / 19 ; 68.4 \%)$ were $\leqslant 97 \%$ similar to their closest BLAST match compared with epilithon isolates (18/37; 48.6\%). Bowman et al. (1997) conducted a similar cultivation-based study of heterotrophic Antarctic sea-ice bacteria and retrieved many extremely novel members of the Flavobacteriaceae. Suzuki et al. (1997) also cultured many novel marine heterotrophic bacteria on high-nutrient agar. They concluded that either this marine bacterial cultivation approach had not yet been exhausted or these novel bacteria had previously been isolated but their 16S rRNA gene sequences had not been submitted to public databases.

These cultivation studies suggest that the marine environment contains greater 'Bacteroidetes' diversity than the freshwater epilithon. However, these differences might in part be due to sampling epilithon in the freshwater site 


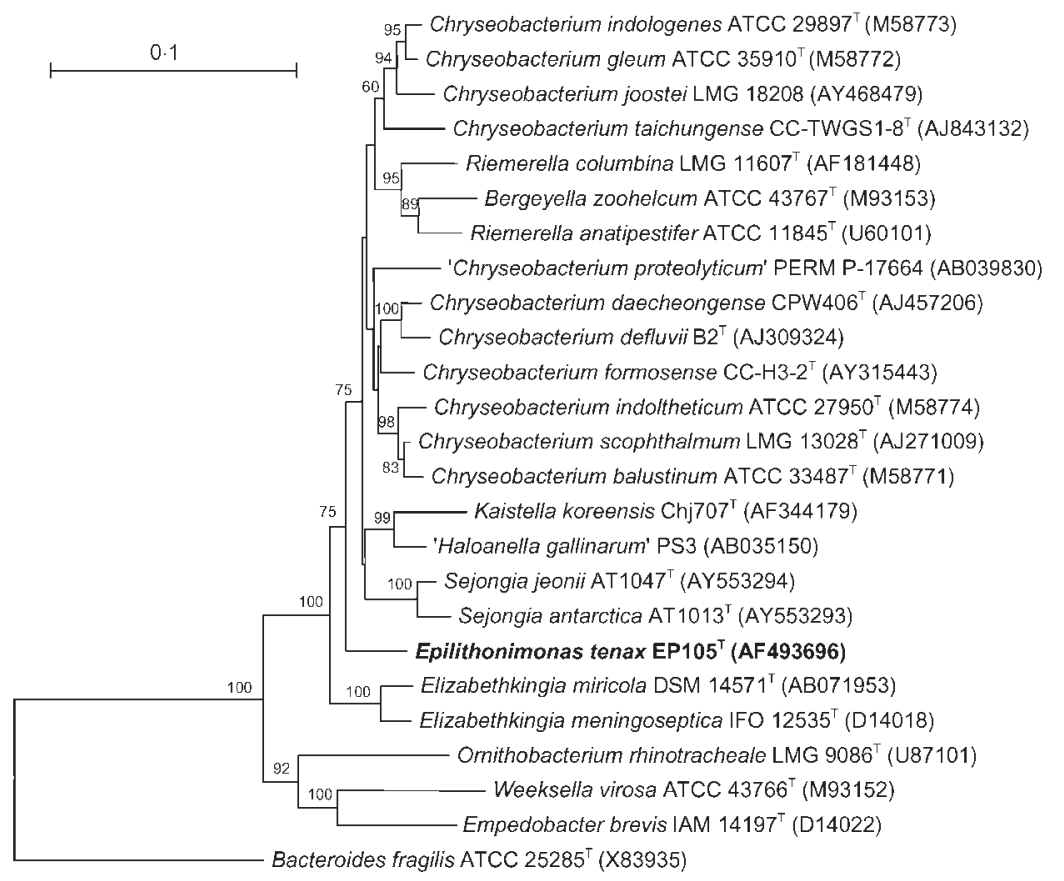

Fig. 4. Phylogenetic tree of $16 \mathrm{~S}$ rRNA gene sequences illustrating relationships between River Taff epilithon 'Bacteroidetes' isolate $\mathrm{EP} 105^{\top}$ and members of the genera Chryseobacterium, Bergeyella, Elizabethkingia, Kaistella, Riemerella and Sejongia. The tree was constructed as described for Fig. 2. Bootstrap values from 100 replicate trees are shown at the nodes. Bar, $10 \%$ difference in nucleotide sequence. and sea water in the coastal site. There was very little overlap between the epilithic 'Bacteroidetes' diversity estimated from this study and a molecular-based 16S rRNA gene clone library study of River Taff epilithon (O'Sullivan et al., 2002). Only one epilithon clone was $>97 \%$ similar to a cultivated cellular isolate (clone TAF-B87 and isolates EP209 and EP235). The cultivation approach successfully retrieved isolates from the genus Flavobacterium, and to a lesser extent Chryseobacterium, Pedobacter and Flectobacillus, but did not isolate the majority of members of the 'Bacteroidetes' found in the 16S rRNA gene libraries, such as the large group of 'Taxeobacter' and Hymenobacter clones.

In general, the standard agar-based cultivation approach utilized in this study successfully isolated bacteria from the family Flavobacteriaceae, but appeared to be inappropriate for isolating other members of the 'Bacteroidetes'. The reasons for this are likely to be numerous: the cultivation technique may discriminate against the isolation of anaerobic, facultatively aerobic, psychrophilic, oligotrophic, filamentous or specialized cellulose-degrading bacteroidetes. Consequently, there is a need for more innovative cultivation methods to isolate the most abundant and ecologically significant aquatic members of the 'Bacteroidetes', but no single technique can be expected to cultivate all of the physiological diversity within the phylum (Suzuki et al., 1997). However, this study does illustrate that routine isolation on high-nutrient agar still yields novel isolates of the Flavobacteriaceae worthy of further investigation. More targeted approaches have successfully isolated novel members of other families within the 'Bacteroidetes'. For example, Bowman et al. (2003) used a mixture of broth culture and agar plates incubated at $2-4{ }^{\circ} \mathrm{C}$ for at least $4-6$ weeks to isolate three new genera within the novel family designated Cryomorphaceae. However, isolates from two other genera in this family were subsequently isolated on agar incubated at $20-30{ }^{\circ} \mathrm{C}$ for 3-6 days (Lau et al., 2005; O’Sullivan et al., 2005). One of these studies used hybridization with a groupspecific, phylogenetic probe to screen many isolates for bacteria related to the novel target group (O'Sullivan et al., 2005). These and other targeted approaches that have been successful within other phyla (Fry, 2004) might well be applied for isolating novel, abundant members of the 'Bacteroidetes'.

\section{Polyphasic characterization of isolates EP105 and $\mathrm{SW}^{256^{\mathrm{T}}}$}

One River Taff epilithon strain $\left(\mathrm{EP} 105^{\mathrm{T}}\right)$ and one Hope Cove coastal sea-water strain $\left(\right.$ SW256 ${ }^{\mathrm{T}}$ ) were selected for polyphasic characterization, in accordance with the proposed minimal standards for describing new taxa of the family Flavobacteriaceae (Bernardet et al., 2002). These isolates were selected because they both branched deeply between genera within 16S rRNA gene sequence-based phylogenetic trees (Figs 3 and 4). Sequence analysis of their $16 \mathrm{~S}$ rRNA genes revealed that both strains were affiliated with the family Flavobacteriaceae (Figs 3 and 4).

Strain $\mathrm{EP} 105^{\mathrm{T}}$ belonged to a monophyletic cluster containing the genera Bergeyella, Chryseobacterium, Elizabethkingia, Kaistella, Riemerella and Sejongia (commonly termed the Chryseobacterium-Bergeyella-Riemerella branch; Vandamme et al., 1994). EP $105^{\mathrm{T}}$ formed a discrete lineage positioned between the genus Elizabethkingia and the other genera (Fig. 3; bootstrap $75 \%$ ). This separate branch 
Table 3. Major whole-cell fatty acid content of Epilithonimonas tenax EP105 ${ }^{\top}$, Persicivirga xylanidelens SW $256^{\top}$, Elizabethkingia meningoseptica and Chryseobacterium indoltheticum

Taxa: 1, EP105 ${ }^{\mathrm{T}}$ (this study); 2a, E. meningoseptica NCTC $10016^{\mathrm{T}}$ (this study); 2b, E. meningoseptica LMG $12279^{\mathrm{T}}$ (Kämpfer et al., 2003); 3a, C. indoltheticum NCIMB $2220^{\mathrm{T}}$ (this study); 3b, C. indoltheticum LMG $4025^{\mathrm{T}}$ (Kämpfer et al., 2003): 4, SW256 ${ }^{\mathrm{T}}$ (this study). Two structural unspecified compounds (ECL 13.566 and ECL 16.580) identified by Kämpfer et al. (2003) are not included in this table. ECL $13 \cdot 566$ may be identical to iso $14: 0$. tr, Trace $<0 \cdot 1 \%$.

\begin{tabular}{|c|c|c|c|c|c|c|}
\hline \multirow[t]{2}{*}{ Fatty acid } & \multicolumn{6}{|c|}{ Content (\% of total) } \\
\hline & 1 & $2 a$ & $2 \mathbf{b}$ & $3 a$ & $3 b$ & 4 \\
\hline \multicolumn{7}{|l|}{ Saturated fatty acids: } \\
\hline $15: 0$ & & & & & & $5 \cdot 5$ \\
\hline $16: 0$ & $8 \cdot 0$ & $1 \cdot 8$ & $\operatorname{tr}$ & $0 \cdot 9$ & $1 \cdot 3$ & $\operatorname{tr}$ \\
\hline Sum & $8 \cdot 0$ & $1 \cdot 8$ & $0 \cdot 0$ & $0 \cdot 9$ & $1 \cdot 3$ & $5 \cdot 5$ \\
\hline \multicolumn{7}{|l|}{$\begin{array}{l}\text { Saturated branched-chain } \\
\text { fatty acids: }\end{array}$} \\
\hline iso $13: 0$ & $0 \cdot 9$ & $0 \cdot 9$ & $1 \cdot 9$ & & $\operatorname{tr}$ & $\operatorname{tr}$ \\
\hline iso $14: 0$ & $4 \cdot 3$ & $5 \cdot 8$ & & $6 \cdot 0$ & & $3 \cdot 2$ \\
\hline anteiso $14: 0$ & $1 \cdot 2$ & & & $1 \cdot 3$ & & $2 \cdot 6$ \\
\hline iso $15: 0$ & $20 \cdot 0$ & $40 \cdot 2$ & $42 \cdot 1$ & $27 \cdot 1$ & $34 \cdot 1$ & $18 \cdot 1$ \\
\hline anteiso $15: 0$ & $14 \cdot 5$ & $4 \cdot 5$ & $1 \cdot 9$ & $5 \cdot 4$ & $5 \cdot 3$ & $21 \cdot 6$ \\
\hline iso $16: 0$ & & & & & & $3 \cdot 3$ \\
\hline iso $17: 0$ & $\operatorname{tr}$ & $\operatorname{tr}$ & $\operatorname{tr}$ & $\operatorname{tr}$ & $1 \cdot 0$ & $\operatorname{tr}$ \\
\hline Sum & $41 \cdot 0$ & $51 \cdot 4$ & $45 \cdot 9$ & $39 \cdot 8$ & $40 \cdot 4$ & $48 \cdot 8$ \\
\hline \multicolumn{7}{|l|}{$\begin{array}{l}\text { Unsaturated branched-chain } \\
\text { fatty acids: }\end{array}$} \\
\hline iso $13: 1^{*}$ & & & & & & $1 \cdot 9$ \\
\hline iso $16: 1^{*}$ & & & & & & $1 \cdot 4$ \\
\hline iso $17: 1 \omega 9 c$ & $1 \cdot 0$ & $6 \cdot 8$ & $4 \cdot 6$ & $30 \cdot 0$ & $21 \cdot 7$ & $8 \cdot 5$ \\
\hline Sum & $1 \cdot 0$ & $6 \cdot 8$ & $4 \cdot 6$ & $30 \cdot 0$ & $21 \cdot 7$ & $11 \cdot 8$ \\
\hline \multicolumn{7}{|l|}{ Monosaturated fatty acids: } \\
\hline $13: 1^{*}$ & $2 \cdot 3$ & $1 \cdot 0$ & & & & $\operatorname{tr}$ \\
\hline $15: 1^{\star}$ & & & & & & $1 \cdot 4$ \\
\hline $16: 1 \omega 7 c /$ iso $15: 02-\mathrm{OH}$ & $21 \cdot 1$ & $17 \cdot 3$ & $17 \cdot 3$ & $9 \cdot 8$ & $10 \cdot 2$ & $5 \cdot 3$ \\
\hline Sum & $23 \cdot 5$ & $18 \cdot 3$ & $17 \cdot 3$ & $9 \cdot 8$ & $10 \cdot 2$ & $6 \cdot 7$ \\
\hline \multicolumn{7}{|l|}{ Hydroxy fatty acids: } \\
\hline iso $15: 03-\mathrm{OH}$ & $1 \cdot 6$ & $2 \cdot 7$ & $3 \cdot 7$ & $1 \cdot 8$ & $2 \cdot 0$ & $6 \cdot 9$ \\
\hline anteiso $15: 03-\mathrm{OH}$ & & & & & & $2 \cdot 2$ \\
\hline iso $16: 03-\mathrm{OH}$ & $1 \cdot 9$ & $1 \cdot 6$ & $1 \cdot 1$ & $1 \cdot 3$ & $\operatorname{tr}$ & $4 \cdot 7$ \\
\hline $16: 03-\mathrm{OH}$ & $5 \cdot 9$ & $2 \cdot 8$ & $2 \cdot 3$ & $0 \cdot 9$ & $1 \cdot 1$ & $\operatorname{tr}$ \\
\hline iso $17: 03-\mathrm{OH}$ & $9 \cdot 8$ & $13 \cdot 2$ & $17 \cdot 6$ & $11 \cdot 0$ & $15 \cdot 4$ & $7 \cdot 1$ \\
\hline anteiso $17: 03-\mathrm{OH}$ & $2 \cdot 5$ & & & $2 \cdot 2$ & & $4 \cdot 9$ \\
\hline Sum & $21 \cdot 6$ & $20 \cdot 3$ & $24 \cdot 7$ & $17 \cdot 4$ & $18 \cdot 5$ & $25 \cdot 8$ \\
\hline
\end{tabular}

* Unspecified position and configuration of double bond.

provides strong support for this strain representing a novel genus. Some members of the Chryseobacterium-BergeyellaRiemerella branch have also been isolated from freshwater environments. For example, Chryseobacterium daecheongense and Kaistella koreensis were isolated from freshwater lake sediment and a freshwater stream, respectively (Kim et al., 2004, 2005a). However, many members of this branch seem to have a propensity for colonizing higher animals, having been isolated from human clinical samples, birds and fish. This branch may typically contain free-living bacteria which can colonize higher animals opportunistically and cause disease, in much the same way as members of the Burkholderia cepacia complex (Mahenthiralingam et al., 2005).

The sea-water strain SW $256^{\mathrm{T}}$ affiliated with the large marine Flavobacteriaceae branch and formed a low bootstrap grouping with members of the genus Cellulophaga (Fig. 3). This isolate was not easy to place phylogenetically, as its position varied according to the other sequences in the analysis. In other trees, it was more closely associated with the genera Psychroflexus, Gillisia, Mesonia and Salegentibacter or formed a separate branch on its own (not shown). However, SW $256^{\mathrm{T}}$ exhibited $<90 \%$ 16S rRNA gene sequence similarity to any recognized species within the Flavobacteriaceae, indicating that this strain also represents a new genus.

Strain EP $105^{\mathrm{T}}$ was originally isolated on M1 medium and produced bright-orange, opaque, smooth, raised colonies (3-6 $\mathrm{mm}$ diameter) with an entire edge and a viscous consistency on PCA after 1 week at $20^{\circ} \mathrm{C}$ (Fig. 1d). The cells of $\mathrm{EP} 105^{\mathrm{T}}$ were short, rounded rods which did not form chains or filaments and were $1-2.5 \mu \mathrm{m}$ long and $0.6-$ $0 \cdot 7 \mu \mathrm{m}$ wide. Strain SW256 ${ }^{\mathrm{T}}$ was isolated on CYT plus aged sea water and produced peach-coloured, opaque, smooth, raised colonies (1-2 mm diameter) with an entire edge and creamy consistency (Fig. 10). The cells of SW $256^{\mathrm{T}}$ were long, irregularly straight to curved rods with rounded ends, which were $2 \cdot 2-7 \cdot 5 \mu \mathrm{m}$ in length and $0 \cdot 5-0 \cdot 6 \mu \mathrm{m}$ in width. Neither strain produced gliding cells or spreading colonies on any agar tested.

The physiological and biochemical characteristics of strains $\mathrm{EP} 105^{\mathrm{T}}$ and SW256 ${ }^{\mathrm{T}}$ are listed in the species descriptions. Table 1 lists the phenotypic characteristics that distinguish strain $\mathrm{EP} 105^{\mathrm{T}}$ from some phylogenetically related species of the genera Bergeyella, Chryseobacterium, Elizabethkingia, Kaistella, Riemerella and Sejongia. $\mathrm{EP} 105^{\mathrm{T}}$ could be distinguished from members of the aforementioned genera by three to 11 known phenotypic characteristics. In addition, the members of genera described in Table 1 can usually be distinguished from $\mathrm{EP} 105^{\mathrm{T}}$ and each other by the following observations. Absence of yellow pigment distinguishes Elizabethkingia, Bergeyella and Riemerella strains. Growth on marine agar is variable for species of Chryseobacterium, positive for Elizabethkingia and Sejongia and negative for Riemerella, Bergeyella and Epilithonimonas. Capnophilic metabolism occurs in Riemerella species only. Table 2 lists the phenotypic characteristics that differentiate strain SW $256^{\mathrm{T}}$ from phylogenetically related marine genera of the family Flavobacteriaceae. SW $256^{\mathrm{T}}$ required $\mathrm{NaCl}$ for growth and was unable to utilize any of the substrates included in the API 20NE or Biolog GN2 commercial arrays. 
SW256 ${ }^{\mathrm{T}}$ could be distinguished from related marine genera by three to nine known phenotypic characteristics.

The fatty acid profiles of SW $256^{\mathrm{T}}, \mathrm{EP} 105^{\mathrm{T}}$ and two phylogenetically related species of the family Flavobacteriaceae are shown in Table 3. The uncertain, deep-branching phylogenetic position of SW $256^{\mathrm{T}}$ made it difficult to identify suitable cultures for comparison. Although SW256 ${ }^{\mathrm{T}}$ contained a wider range of fatty acids than $\mathrm{EP} 105^{\mathrm{T}}$, both bacteria are characterized by large amounts of branched as well as hydroxy fatty acids, contributing over $60 \%$ to the total fatty acid content. In comparison with the phylogenetically related species, the novel strains show large relative proportions of the anteiso compounds. Fatty acid profiles obtained for reference strains in this study were in agreement with previously published profiles (Kämpfer et al., 2003). There were clear differences between EP105 ${ }^{\mathrm{T}}$, E. meningoseptica and C. indoltheticum for fatty acids 16:0, iso $17: 1 \omega 9 c$ and the combined peak $16: 1 \omega 7 c /$ iso $15: 02$ $\mathrm{OH}$ (usually called summed feature 3 ). These and some other differences useful in taxonomic assignment are consistent with other data for related strains presented recently (Kim et al., 2005b).

Strains EP $105^{\mathrm{T}}$ and SW256 ${ }^{\mathrm{T}}$ had DNA G $+\mathrm{C}$ contents of 37.5 and $34.7 \mathrm{~mol} \%$, respectively, which are consistent with the values observed in the family Flavobacteriaceae (27-44 mol\%; Bernardet et al., 2002). Mean DNA-DNA hybridization values for EP $105^{\mathrm{T}}$ and E. meningoseptica and for $\mathrm{EP} 105^{\mathrm{T}}$ and C. indoltheticum were 35.3 and $20 \cdot 8 \%$, respectively, demonstrating that $\mathrm{EP} 105^{\mathrm{T}}$ is not closely related to the genera Chryseobacterium or Elizabethkingia.

\section{Description of Epilithonimonas gen. nov.}

Epilithonimonas [Ep'i.lith.on.i.mo'nas. N.L. n. epilithon -is (or epilithonum -i) epilithon; L. fem. n. monas a unit, monad; N.L. fem. n. Epilithonimonas a monad isolated from epilithon].

Short, rod-shaped, non-flagellated, Gram-negative cells. Strictly aerobic. Carbohydrates are utilized for growth. Cytochrome oxidase- and catalase-positive. Fatty acids contain a large proportion of saturated branched-chain, monosaturated and hydroxy fatty acids. The most abundant individual fatty acids are iso 15:0 and summed feature 3 $(16: 1 \omega 7 c /$ iso $15: 0$ 2-OH). Isolated from freshwater environments and do not require the presence of $\mathrm{Na}^{+}$ ions. Analysis of the 16S rRNA gene sequences indicate that the genus Epilithonimonas is a member of the family Flavobacteriaceae of the phylum 'Bacteroidetes'. The type species is Epilithonimonas tenax.

\section{Description of Epilithonimonas tenax sp. nov.}

Epilithonimonas tenax (ten'ax. L. fem. adj. tenax sticky, holding firm, referring to the organism's viscous colonies).

Exhibits the following characteristics in addition to those properties described for the genus. Colonies are 3-6 $\mathrm{mm}$ in diameter, bright orange, opaque, smooth, with an entire edge and a viscous consistency (PCA after 1 week at $20^{\circ} \mathrm{C}$ ). Cells are short, rounded rods which do not form chains or filaments and are $1-2 \cdot 5 \mu \mathrm{m}$ long and $0 \cdot 6-0 \cdot 7 \mu \mathrm{m}$ wide. Cells do not exhibit gliding motility. Cell mass is pigmented orange and flexirubin pigments are synthesized. Growth occurs between 4 and $30^{\circ} \mathrm{C}$, but not in the presence of $\mathrm{NaCl}$. Nitrate is reduced, but nitrite is not reduced. Growth occurs on TSA, NA, MacConkey agar and DNase agar, but not on MA2216 or cetrimide agar. Aesculin and starch are hydrolysed. Agar, arginine, DNA, Tween 80 and gelatin are not hydrolysed. Indole is not produced. No $\beta$-galactosidase, urease or xylanase activities. Acid is not produced from glucose. Resistant to chloramphenicol, streptomycin, kanamycin and tetracycline, but susceptible to penicillin G, ampicillin and rifampicin. Growth occurs on glucose, mannose, maltose, $\alpha$-cyclodextrin, dextrin, glycogen, Tween 40 , gentiobiose, $\alpha$-D-glucose, sucrose, D-trehalose, acetic acid, $\alpha$-ketovaleric acid, L-alanyl-glycine, L-glutamic acid, glycyl-Laspartic acid, glycyl-L-glutamic acid, L-ornithine, L-proline, L-serine, L-threonine, inosine, uridine and thymidine. Growth does not occur on arabinose, mannitol, $\mathrm{N}$ acetylglucosamine, gluconate, caprate, adipate, malate, citrate, phenylacetate, Tween $80, \mathrm{~N}$-acetyl-D-galactosamine, adonitol, D-arabitol, cellobiose, i-erythritol, D-fructose, L-fucose, D-galactose, myo-inositol, $\alpha$-D-lactose, lactulose, D-melibiose, methyl $\beta$-D-glucoside, D-psicose, D-raffinose, L-rhamnose, D-sorbitol, turanose, xylitol, methyl pyruvate, monomethyl succinate, cis-aconitic acid, citric acid, formic acid, D-galactonic acid, D-galacturonic acid, D-gluconic acid, D-glucosaminic acid, D-glucuronic acid, $\alpha$-hydroxybutyric acid, $\beta$-hydroxybutyric acid, $\gamma$-hydroxybutyric acid, $p$ hydroxyphenylacetic acid, itaconic acid, $\alpha$-ketobutyric acid, $\alpha$-ketoglutaric acid, DL-lactic acid, malonic acid, propionic acid, quinic acid, D-saccharic acid, sebacic acid, succinic acid, bromosuccinic acid, succinamic acid, glucuronamide, alaninamide, D-alanine, L-alanine, L-asparagine, L-aspartic acid, L-histidine, hydroxy-L-proline, L-leucine, Lphenylalanine, L-pyroglutamic acid, D-serine, DL-carnitine, $\gamma$-aminobutyric acid, urocanic acid, phenylethylamine, putrescine, 2-aminoethanol, 2,3-butanediol, glycerol, D,L$\alpha$-glycerol phosphate, glucose 1-phosphate or glucose 6phosphate. The DNA G $+\mathrm{C}$ content of the type strain is $37 \cdot 5 \mathrm{~mol} \%$.

The type strain, $\mathrm{EP} 105^{\mathrm{T}}\left(=\mathrm{NCIMB} 14026^{\mathrm{T}}=\mathrm{DSM} 16811^{\mathrm{T}}\right)$, was isolated from epilithon-covered stones from the River Taff in Cardiff, UK.

\section{Description of Persicivirga gen. nov.}

Persicivirga (Per.si.ci.vir'ga. L. neut. n. persicum peach; L. fem. n. virga rod; N.L. fem. n. Persicivirga peach-coloured rod).

Long, irregularly straight to curved, Gram-negative rods with no visible flagella. Strictly aerobic. Do not utilize carbohydrates for growth. Oxidase- and catalase-negative. The most abundant fatty acids are saturated branched-chain, 
unsaturated branched-chain and hydroxy fatty acids; iso 15:0 and anteiso 15:0 are the most abundant individual fatty acids. Isolated from marine environments and require $\mathrm{Na}^{+}$ions or natural sea water for growth. 16S rRNA gene sequence analysis indicates that the genus Persicivirga is a member of the family Flavobacteriaceae of the phylum 'Bacteroidetes'. The type species is Persicivirga xylanidelens.

\section{Description of Persicivirga xylanidelens sp. nov.}

Persicivirga xylanidelens (xy.lan.i.del'ens. N.L. n. xylanum xylan; L. part. adj. delens destroying; N.L. part. adj. xylanidelens xylan-destroying).

Exhibits the following characteristics in addition to those properties described for the genus. Colonies are 1-2 $\mathrm{mm}$ in diameter, peachy-orange, opaque, smooth with an entire edge and creamy consistency (PCA plus artificial sea water for 1 week at $20^{\circ} \mathrm{C}$ ). Cells have rounded ends and are $2 \cdot 2-7 \cdot 5 \mu \mathrm{m}$ long and $0 \cdot 5-0 \cdot 6 \mu \mathrm{m}$ wide. Cells do not exhibit gliding motility. Cell mass is pigmented orange and flexirubin pigments are synthesized. Growth occurs at 4 and $20{ }^{\circ} \mathrm{C}$ and on $5 \%$, but not $10 \%, \mathrm{NaCl}$. Growth occurs on MA2216, but not on TSA, NA, MacConkey agar, cetrimide agar or DNase agar containing $2 \cdot 5 \% \mathrm{NaCl}$. Xylanase activity is present, but urease activity is absent. Tween 80 and gelatin are hydrolysed, but agar, arginine, aesculin or starch are not hydrolysed. Nitrate and nitrite are not reduced. Indole is not produced. Acid is not produced from glucose. Resistant to chloramphenicol, penicillin G, streptomycin, kanamycin, ampicillin and tetracycline, but sensitive to rifampicin. Growth is not detected for any substrates included in the API 20NE and Biolog GN2 commercial arrays. The DNA $\mathrm{G}+\mathrm{C}$ content of the type strain is $34 \cdot 7 \mathrm{~mol} \%$.

The type strain, SW $256^{\mathrm{T}} \quad\left(=\mathrm{NCIMB} \quad 14027^{\mathrm{T}}=\mathrm{DSM}\right.$ $16809^{\mathrm{T}}$ ), was isolated from coastal sea water, Hope Cove, near Plymouth, UK.

\section{ACKNOWLEDGEMENTS}

This work was supported by a Biotechnology and Biological Sciences Research Council (BBSRC) and Syngenta Industrial CASE Studentship awarded to Louise A. O'Sullivan.

\section{REFERENCES}

Bernardet, J.-F., Segers, P., Vancanneyt, M., Berthe, F., Kersters, K. \& Vandamme, P. (1996). Cutting a Gordian knot: emended classification and description of the genus Flavobacterium, emended description of the family Flavobacteriaceae, and proposal of Flavobacterium hydatis nom. nov. (basonym, Cytophaga aquatilis Strohl and Tait 1978). Int J Syst Bacteriol 46, 128-148.

Bernardet, J.-F., Nakagawa, Y. \& Holmes, B. (2002). Proposed minimal standards for describing new taxa of the family Flavobacteriaceae and emended description of the family. Int J Syst Evol Microbiol 52, 1049-1070.

Böckelmann, U., Manz, W., Neu, T. R. \& Szewzyk, U. (2000). Characterization of the microbial community of lotic organic aggregates ('river snow') in the Elbe River of Germany by cultivation and molecular methods. FEMS Microbiol Ecol 33, 157-170.

Bowman, J. P., McCammon, S. A., Brown, M. V., Nichols, D. S. \& McMeekin, T. A. (1997). Diversity and association of psychrophilic bacteria in Antarctic sea ice. Appl Environ Microbiol 63, 3068-3078.

Bowman, J. P., McCammon, S. A., Lewis, T., Skerratt, J. H., Brown, J. L., Nichols, D. S. \& McMeekin, T. A. (1998). Psychroflexus torquis gen. nov., sp. nov., a psychrophilic species from Antarctic sea ice, and reclassification of Flavobacterium gondwanense (Dobson et al. 1993) as Psychroflexus gondwanense gen. nov., comb. nov. Microbiology 144, 1601-1609.

Bowman, J. P., Nichols, C. M. \& Gibson, J. A. E. (2003). Algoriphagus ratkowskyi gen. nov., sp. nov., Brumimicrobium glaciale gen. nov., sp. nov., Cryomorpha ignava gen. nov., sp. nov. and Crocinitomix catalasitica gen. nov., sp. nov., novel flavobacteria isolated from various polar habitats. Int J Syst Evol Microbiol 53, 1343-1355.

Brettar, I., Christen, R. \& Höfle, M. G. (2004). Belliella baltica gen. nov., sp. nov., a novel marine bacterium of the CytophagaFlavobacterium-Bacteroides group isolated from surface water of the central Baltic Sea. Int J Syst Evol Microbiol 54, 65-70.

Brown, M. V. \& Bowman, J. P. (2001). A molecular phylogenetic survey of sea-ice microbial communities (SIMCO). FEMS Microbiol Ecol 35, 267-275.

Burton, N. F., Day, M. J. \& Bull, A. T. (1982). Distribution of bacterial plasmids in clean and polluted sites in a South Wales river. Appl Environ Microbiol 44, 1026-1029.

Christensen, P. J. \& Cook, F. D. (1972). The isolation and enumeration of cytophagas. Can J Microbiol 18, 1933-1939.

Cottrell, M. T. \& Kirchman, D. L. (2000a). Natural assemblages of marine proteobacteria and members of the Cytophaga-Flavobacter cluster consuming low- and high-molecular-weight dissolved organic matter. Appl Environ Microbiol 66, 1692-1697.

Cottrell, M. T. \& Kirchman, D. L. (2000b). Community composition of marine bacterioplankton determined by $16 \mathrm{~S}$ rRNA gene clone libraries and fluorescence in situ hybridization. Appl Environ Microbiol 66, 5116-5122.

Dawson, R. M. C., Elliot, W. H. \& Jones, K. M. (editors) (1969). Data for Biochemical Research. Oxford: Clarendon Press.

De Ley, J., Cattoir, H. \& Reynaerts, A. (1970). The quantitative measurement of DNA hybridization from renaturation rates. Eur J Biochem 12, 133-142.

Dobson, S. J., Colwell, R. R., McMeekin, T. A. \& Franzmann, P. D. (1993). Direct sequencing of the polymerase chain reaction-amplified $16 \mathrm{~S}$ rRNA gene of Flavobacterium gondwanense sp. nov. and Flavobacterium salegens sp. nov., two new species from a hypersaline Antarctic lake. Int J Syst Bacteriol 43, 77-83.

Flint, K. P. (1985). A note on a selective agar medium for the enumeration of Flavobacterium species in water. J Appl Bacteriol 59, 561-566.

Fry, J. C. (2004). Culture-dependent microbiology. In Microbial Diversity and Bioprospecting, pp. 80-87. Edited by A. T. Bull. Washington, DC: American Society for Microbiology.

Glöckner, F. O., Fuchs, B. M. \& Amann, R. (1999). Bacterioplankton compositions of lakes and oceans: a first comparison based on fluorescence in situ hybridization. Appl Environ Microbiol 65, 3721-3726.

Gosink, J. J., Woese, C. R. \& Staley, J. T. (1998). Polaribacter gen. nov., with three new species, $P$. irgensii sp. nov., $P$. franzmannii sp. nov. and $P$. filamentus sp. nov., gas vacuolate polar marine bacteria of the Cytophaga-Flavobacterium-Bacteroides group and reclassification of 'Flectobacillus glomeratus' as Polaribacter glomeratus comb. nov. Int J Syst Bacteriol 48, 223-235. 
Holmes, B. (1992). The genera Flavobacterium, Sphingobacterium, and Weeksella. In The Prokaryotes, 2nd edn, vol. 4, pp. 3620-3630. Edited by A. Balows, H. G. Trüper, M. Dworkin, W. Harder \& K. H. Schleifer. Berlin: Springer.

Humphry, D. R., George, A., Black, G. W. \& Cummings, S. P. (2001). Flavobacterium frigidarium sp. nov., an aerobic, psychrophilic, xylanolytic and laminarinolytic bacterium from Antarctica. Int J Syst Evol Microbiol 51, 1235-1243.

Huß, V. A. R., Festl, H. \& Schleifer, K. H. (1983). Studies on the spectrophotometric determination of DNA hybridization from renaturation rates. Syst Appl Microbiol 4, 184-192.

Ivanova, E. P., Alexeeva, Y. V., Flavier, S., Wright, J. P., Zhukova, N. V., Gorshkova, N. M., Mikhailov, V. V., Nicolau, D. V. \& Christen, R. (2004). Formosa algae gen. nov., sp. nov., a novel member of the family Flavobacteriaceae. Int J Syst Evol Microbiol 54, 705-711.

Johansen, J. E., Nielsen, P. \& Sjøholm, C. (1999). Description of Cellulophaga baltica gen. nov., sp. nov. and Cellulophaga fucicola gen. nov., sp. nov. and reclassification of [Cytophaga] lytica to Cellulophaga lytica gen. nov., comb. nov. Int J Syst Bacteriol 49, 1231-1240.

Kämpfer, P., Dreyer, U., Neef, A., Dott, W. \& Busse, H.-J. (2003). Chryseobacterium defluvii sp. nov., isolated from wastewater. Int J Syst Evol Microbiol 53, 93-97.

Kim, M. K., Im, W.-T., Shin, Y. K., Lim, J. H., Kim, S.-H., Lee, B. C., Park, M.-Y., Lee, K. Y. \& Lee, S.-T. (2004). Kaistella koreensis gen. nov., sp. nov., a novel member of the ChryseobacteriumBergeyella-Riemerella branch. Int J Syst Evol Microbiol 54, 2319-2324.

Kim, K. K., Bae, H.-S., Schumann, P. \& Lee, S.-T. (2005a). Chryseobacterium daecheongense sp. nov., isolated from freshwater lake sediment. Int J Syst Evol Microbiol 55, 133-138.

Kim, K. K., Kim, M. K., Lim, J. H., Park, H. Y. \& Lee, S.-T. (2005b). Transfer of Chryseobacterium meningosepticum and Chryseobacterium miricola to Elizabethkingia gen. nov. as Elizabethkingia meningoseptica comb. nov. and Elizabethkingia miricola comb. nov. Int J Syst Evol Microbiol 55, 1287-1293.

Lau, K. W. K., Ng, C. Y. M., Ren, J., Lau, S. C. L., Qian, P.-Y., Wong, P.-K., Lau, T. C. \& Wu, M. (2005). Owenweeksia hongkongensis gen. nov., sp. nov., a novel marine bacterium of the phylum 'Bacteroidetes'. Int J Syst Evol Microbiol 55, 1051-1057.

Mahenthiralingam, E., Urban, T. A. \& Goldburg, J. B. (2005). The multifarious, multireplicon Burkholderia cepacia complex. Nat Rev Microbiol 3, 144-156.

Manz, W., Amann, R., Ludwig, W., Vancanneyt, M. \& Schleifer, K. H. (1996). Application of a suite of $16 \mathrm{~S}$ rRNA-specific oligonucleotide probes designed to investigate bacteria of the phylum cytophagaflavobacter-bacteroides in the natural environment. Microbiology 142, 1097-1106.

McCammon, S. A. \& Bowman, J. P. (2000). Taxonomy of Antarctic Flavobacterium species: description of Flavobacterium gillisiae sp. nov., Flavobacterium tegetincola sp. nov., and Flavobacterium xanthum sp. nov., nom. rev. and reclassification of [Flavobacterium] salegens as Salegentibacter salegens gen. nov., comb. nov. Int J Syst Evol Microbiol 50, 1055-1063.

McCammon, S. A., Innes, B. H., Bowmann, J. P., Franzmann, P. D., Dobson, S. J., Holloway, P. E., Skerratt, J. H., Nichols, P. D. \& Rankin, L. M. (1998). Flavobacterium hibernum sp. nov., a lactoseutilizing bacterium from a freshwater Antarctic lake. Int J Syst Bacteriol 48, 1405-1412.

Nedashkovskaya, O. I., Kim, S. B., Han, S. K. \& 7 other authors (2003). Mesonia algae gen. nov., sp. nov., a novel marine bacterium of the family Flavobacteriaceae isolated from the green alga Acrosiphonia sonderi (Kütz) Kornm. Int J Syst Evol Microbiol 53, 1967-1971.
Nedashkovskaya, O. I., Kim, S. B., Han, S. K. \& 7 other authors (2004a). Maribacter gen. nov., a new member of the family Flavobacteriaceae, isolated from marine habitats, containing the species Maribacter sedimenticola sp. nov., Maribacter aquivivus sp. nov., Maribacter orientalis sp. nov. and Maribacter ulvicola sp. nov. Int J Syst Evol Microbiol 54, 1017-1023.

Nedashkovskaya, O. I., Kim, S. B., Han, S. K., Rhee, M. S., Lysenko, A. M., Falsen, E., Frolova, G. M., Mikhailov, V. V. \& Bae, K. S. (2004b). Ulvibacter litoralis gen. nov., sp. nov., a novel member of the family Flavobacteriaceae isolated from the green alga Ulva fenestrata. Int J Syst Evol Microbiol 54, 119-123.

Nedashkovskaya, O. I., Kim, S. B., Han, S. K. \& 9 other authors (2005a). Winogradskyella thalassocola gen. nov., sp. nov., Winogradskyella epiphytica sp. nov. and Winogradskyella eximia sp. nov., marine bacteria of the family Flavobacteriaceae. Int J Syst Evol Microbiol 55, 49-55.

Nedashkovskaya, O. I., Kim, S. B., Lysenko, A. M., Frolova, G. M., Mikhailov, V. V., Lee, K. H. \& Bae, K. S. (2005b). Description of Aquimarina muelleri gen. nov., sp. nov., and proposal of the reclassification of [Cytophaga] latercula Lewin 1969 as Stanierella latercula gen. nov., comb. nov. Int J Syst Evol Microbiol 55, 225-229. Nikitin, D. I., Strömpl, C., Oranskaya, M. S. \& Abraham, W.-R. (2004). Phylogeny of the ring-forming bacterium Arcicella aquatica gen. nov., sp. nov. (ex Nikitin et al. 1994), from a freshwater neuston biofilm. Int J Syst Evol Microbiol 54, 681-684.

O'Sullivan, L. A., Weightman, A. J. \& Fry, J. C. (2002). New degenerate Cytophaga-Flexibacter-Bacteroides-specific 16S ribosomal DNA-targeted oligonucleotide probes reveal high bacterial diversity in River Taff epilithon. Appl Environ Microbiol 68, 201-210.

O'Sullivan, L. A., Fuller, K. E., Thomas, E. M., Turley, C. M., Fry, J. C. \& Weightman, A. J. (2004). Distribution and culturability of the uncultivated 'AGG58 cluster' of the Bacteroidetes phylum in aquatic environments. FEMS Microbiol Ecol 47, 359-370.

O’Sullivan, L. A., Rinna, J., Humphreys, G., Weightman, A. J. \& Fry, J. C. (2005). Fluviicola taffensis gen. nov., sp. nov., a novel freshwater bacterium of the family Cryomorphaceae in the phylum 'Bacteroidetes'. Int J Syst Evol Microbiol 55, 2189-2194.

Paster, B. J., Ludwig, W., Weisberg, W. G., Stackebrandt, E., Hespell, R. B., Hahn, C. M., Reichenbach, H., Stetter, K. O. \& Woese, C. R. (1985). A phylogenetic grouping of the bacteroides, cytophagas, and certain flavobacteria. Syst Appl Microbiol 6, 34-42.

Reichenbach, H. (1989). Nonphotosynthetic, nonfruiting gliding bacteria. Genus 1. Cytophaga Winogradsky 1929, $577^{\mathrm{AL}}$, emend. In Bergey's Manual of Systematic Bacteriology, 2nd edn, vol. 3, pp. 2015-2050. Edited by J. Staley, M. P. Bryant, N. Pfennig \& J. G. Holt. Baltimore: Williams \& Wilkins.

Reichenbach, H. (1992). The order Cytophagales. In The Prokaryotes, 2nd edn, vol. 4, pp. 3631-3687. Edited by A. Balows, H. G. Truper, M. Dworkin, W. Harder \& K. H. Schleifer. Berlin: Springer.

Reichenbach, H., Kohl, W., Böttger-Vetter, A. \& Achenbach, H. (1980). Flexirubin-type pigments in Flavobacterium. Arch Microbiol 126, 291-293.

Rickard, A. H., Stead, A. T. O'May G. A., Lindsay, S., Banner, M., Handley, P. S. \& Gilbert, P. (2005). Adhaeribacter aquaticus gen. nov., sp. nov., a Gram-negative isolate from a potable water biofilm. Int J Syst Evol Microbiol 55, 821-829.

Simon, M., Glöckner, F. O. \& Amann, R. (1999). Different community structure and temperature optima of heterotrophic picoplankton in various regions of the Southern Ocean. Aquat Microb Ecol 18, 275-284.

Smibert, R. M. \& Krieg, N. R. (1994). Phenotypic characterization. In Methods for General and Molecular Bacteriology, pp. 607-654. Edited 
by P. Gerhardt, R. G. E. Murray, W. A. Wood \& N. R. Krieg. Washington, DC: American Society for Microbiology.

Sohn, J. H., Lee, J.-H., Yi, H., Chun, J., Bae, K. S., Ahn, T.-Y. \& Kim, S.-J. (2004). Kordia algicida gen. nov., sp. nov., an algicidal bacterium isolated from red tide. Int J Syst Evol Microbiol 54, 675-680.

Staples, D. G. \& Fry, J. C. (1973). A medium for counting aquatic heterotrophic bacteria in polluted and unpolluted waters. J Appl Bacteriol 36, 179-181.

Suzuki, M. T., Rappé, M. S., Haimberger, Z. W., Winfield, H., Adair, N., Strobel, J. \& Giovannoni, S. J. (1997). Bacterial diversity among small-subunit rRNA gene clones and cellular isolates from the same seawater sample. Appl Environ Microbiol 63, 983-989.

Suzuki, M., Nakagawa, Y., Harayama, S. \& Yamamoto, S. (2001). Phylogenetic analysis and taxonomic study of marine Cytophaga-like bacteria: proposal for Tenacibaculum gen. nov. with Tenacibaculum maritimum comb. nov. and Tenacibaculum ovolyticum comb. nov., and description of Tenacibaculum mesophilum sp. nov. and Tenacibaculum amylolyticum sp. nov. Int J Syst Evol Microbiol 51, 1639-1652.

Tenreiro, S., Nobre, M. F., Rainey, F. A., Miguel, C. \& da Costa, M. S. (1997). Thermonema rossianum sp. nov., a new thermophilic and slightly halophilic species from saline hot springs in Naples, Italy. Int J Syst Bacteriol 47, 122-126.

Vandamme, P., Bernardet, J.-F., Segers, P., Kersters, K. \& Holmes, B. (1994). New perspectives in the classification of the flavobacteria: description of Chryseobacterium gen. nov., Bergeyella gen. nov., and Empedobacter nom. rev. Int J Syst Bacteriol 44, 827-831.

Vandamme, P., Pot, B., Gillis, M., De Vos, P. \& Swings, J. (1996). Polyphasic taxonomy, a consensus approach to bacterial systematics. Microbiol Rev 60, 407-438.

Van Trappen, S., Vandecandelaere, I., Mergaert, J. \& Swings, J. (2004). Gillisia limnaea gen. nov., sp. nov., a new member of the family Flavobacteriaceae isolated from a microbial mat in Lake Fryxell, Antarctica. Int J Syst Evol Microbiol 54, 445-448.

Weeks, O. B. (1955). Flavobacterium aquatile (Frankland and Frankland) Bergey et al., type species of the genus Flavobacterium. J Bacteriol 69, 649-658.

Woese, C. R., Yang, D., Mandelco, L. \& Stetter, K. O. (1990). The Flexibacter-Flavobacter connection. Syst Appl Microbiol 13, 161-165.

Yi, H. \& Chun, J. (2004). Hongiella mannitolivorans gen. nov., sp. nov., Hongiella halophila sp. nov. and Hongiella ornithinivorans sp. nov., isolated from tidal flat sediment. Int J Syst Evol Microbiol 54, 157-162.

Yi, H., Yoon, H. I. \& Chun, J. (2005). Sejongia antarctica gen. nov., sp. nov. and Sejongia jeonii sp. nov., isolated from the Antarctic. Int J Syst Evol Microbiol 55, 409-416.

Young, C.-C., Kämpfer, P., Shen, F.-T., Lai, W.-A. \& Arun, A. B. (2005). Chryseobacterium formosense sp. nov., isolated from the rhizosphere of Lactuca sativa L. (garden lettuce). Int J Syst Evol Microbiol 55, 423-426. 